\title{
Glycemic profile and prebiotic potential "in vitro" of bread with Yacon (Smallanthus sonchifolius) flour
}

\author{
Perfil glicêmico e potencial prebiótico "in vitro" de pães com farinha de yacon (Smallanthus sonchifolius) \\ Priscilla Moura ROLIM ${ }^{1 \star}$, Silvana Magalhães SALGADOํ․ Vivianne Montarroyos PADILHA ${ }^{1}$, \\ Alda Verônica Souza LIVERA ${ }^{1}$, Samara Alvachian Cardoso ANDRADE ${ }^{1}$, Nonete Barbosa GUERRA ${ }^{1}$
}

\begin{abstract}
The purpose of this study was to elaborate bread with yacon flour at two different levels (6\% and $11 \%$ ) and to analyze their proximate composition, their glycemic indices and their prebiotic potentials in vitro. Bread with $6 \%$ and $11 \%$ of yacon flour presented, simultaneously, low and moderate glycemic index. As for the prebiotic potentials, it was evident the presence of probiotic bacteria, particularly Lactobacillus. The results showed that, the addition of yacon flour on bread rendered products from low to moderate GI, with prebiotic potential, low fat and high fiber contents, according to the Brazilian food legislation.

Keywords: bread; yacon flour; glycemic index; prebiotic.
\end{abstract}

\section{Resumo}

A pesquisa teve como objetivo elaborar pães com diferentes níveis de farinha de yacon (6\% e 11\%) e analisá-los quanto à sua composição centesimal, índice glicêmico e potencial prebiótico "in vitro". O pão com $11 \%$ de farinha de yacon mostrou baixo índice glicêmico e com 6\%, índice glicêmico moderado. Quanto ao potencial prebiótico foi evidente a presença de bactérias probióticas, em especial o gênero Lactobacillus. Os resultados mostraram que a adição de farinha de yacon em pães propiciou produtos de baixo a moderado IG, com potencial prebiótico, light em gorduras e teor de fibras elevado, segundo a legislação de vigente.

Palavras-chave: pão; farinha de yacon; índice glicêmico; prebióticos.

\section{Introduction}

Yacon (Smallanthus sonchifolius) is a tuberose root that is very commonly eaten in the Andes region in South America. Lately, it has spread into New Zealand, Japan, Korea and Brazil. It has a slightly sweet flavour, not only from its fructose, glucose and sucrose tenor in its composition, but also from the presence of fruit (insulin and frutoligossacharideos - FOS), being of great interest to food science (VALENTOVÁ et al., 2008; DUARTE; WOLF; PAULA, 2008).

These fructans are defined as non-glycemic carbohydrate, provided that they reach the large intestine without being metabolized, thus being considered as prebiotic carbohydrates of low energetic level (CUMMINGS; STEPHEN, 2007). The insulin and the FOS have bi-fidogenic effects as they contribute to the increase of prebiotic cultures in the colon; notwithstanding, its efficiency depends on the micro-biotic colony of each individual.

In a similar way, soluble fiber, insulin and FOS are good gel making agents and thus, they influence the absorption of macronutrients, especially carbohydrates, delaying the gastric emptying and consequently decreasing the gastrointestinal transit time (SAAD, 2006).
The role of fructans in the glycemic and insulin processes is not complete, indicating that these effects depend on the physiological conditions of each individual. Various studies have shown a positive correlation between yacon ingestion and the reduction of the glycemic response, especially toward diabetic individuals (VALENTOVÁ; ERSEN; ULRICHOVA, 2005).

Diabetic and overweight individuals represent a significant number in the Brazilian population, generating a high budget for public health offices. Researches on the development of new products as source of non-glycemic carbohydrates must be carried out in order to help the glucose control.

Nowadays, the food industry has added nutritional value to their products by adding fibers from a lot of vegetables sources, such as linseed, oat, rye and whole meal flours. The bread industry was one of the pioneers in this process, nevertheless, there are few reports depicting the properties of those bioactive, concerning the nutritional and bi-fidogenic characteristics. (ARENDT et al., 2003).

A recent project carried out in Brasil (2006) prompted studies on the insulin effects over the glycemic index, showing lower rates compared to those found in the literature concerning

${ }^{1}$ Laboratory for Experimentation and Analysis of Foods - LEAAL, Department of Nutrition, Center for Health Sciences, Federal University of Pernambuco - UFPE, Av. Prof. Moraes Rego, 1235, CEP 50670-901, Cidade Universitária, Recife, PE, Brazil, E-mail: priscillanutri@hotmail.com

${ }^{*}$ Corresponding author 
whole meal or oat bread, usually recommended for diabetic and overweight individuals. (FOSTER- POWELL; HOLT; BRANDMILLER, 2002).

The physiologic effects of the bioactive fructans associated to costumers' demand for healthy products motivated the realization of this project, aiming at evaluating the glycemic response and the prebiotic potential 'in vitro' of bread made with yacon flour.

\section{Materials and methods}

\subsection{The yacon flour process and the bread making}

The yacon used for the production of flour was found at the Storage Center (CEASA) in Recife - PE. The process used to obtain the yacon flour is described, according to the stages, in Figure 1. The bread was produced in a Britânia ${ }^{\mathrm{TM}}$ bread machine, according to the manufacturer's instructions. The formulations are detailed in Table 1.

\subsection{Microbiological and granulometrical analysis of the yacon flour}

In order to check the yacon flour inoculum, some analysis of coliforms at $45{ }^{\circ} \mathrm{C}$ were carried out, (Bacillus Cereus and Salmonella sp.) (ASSOCIATION..., 2000) according to the current Brazilian legislation. The yacon flour was characterized according to its granulemetric system, determining the particle size distribution and its average diameter. A $100 \mathrm{~g}$ sample was poured onto a number of sieves $(30,40,50$, 60 and 80 mesh- ABNT) and the Produtest sieves agitator (Telasten Ltda, model T, Sao Paulo, Brazil). This sieve system was subjected to vibration for 10 minutes, having the potentiometer adjusted to the maximum vibration scale (10). After its passage, the percentage of flour left on each sieve was calculated. (MATSUO; DEXTER, 1980).

\subsection{The yacon flour characteristics}

The following physical chemical analyses were carried out: humidity (method 935.29); fixed mineral residue (method 930.22-32.308); proteins (method 991.20-33.2.11); extract etereo (method 963.15-31.4.02); fiber and fraction (method 985.29); and carbohydrates by difference (ASSOCIATION..., 2002).

\subsection{The analysis of bread centesimal composition}

Bread centesimal composition was determined in three copies, according to the AOAC methods (ASSOCIATION..., 2002). Humidity (method 935.29); fix mineral residue (method 930.22-32.308); proteins (method 991.20-33.2.11); extract etereo (method 963.15-31.4.02); fibre and fraction (method 985.29); and carbohydrates by difference (ASSOCIATION..., 2002). The fibre (soluble and insoluble) was determined through the AOAC 985.29, the Quemer et al. (1994) (integrated method, with adaptations - Figure 2) and the total food fiber was calculated through the addition of these fractions.

\subsection{Determination of the glycemic index 'in vitro' and glycemic charge}

In order to determine the glycemic index, bread was sliced and dried in a stove/oven at $105^{\circ} \mathrm{C}$ for 1 hour and then grained. The glycemic index was carried out according to the method developed by Gõni, Garcia-Alonso and Sauro-Caiixto (1997), through a glucose kit. After that, the glycemic index was calculated, as described below, using white bread as the

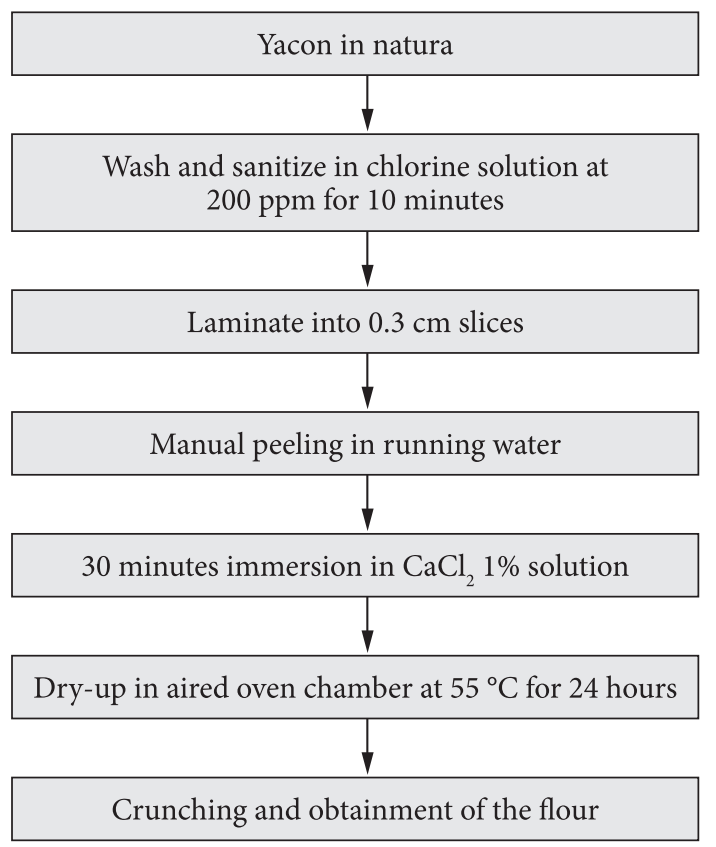

Figure 1. The process to obtain the yacon flour.

Table 1. Ingredients proportion in the making of bread.

\begin{tabular}{|c|c|c|c|}
\hline \multirow[t]{2}{*}{ Ingredients } & \multicolumn{3}{|c|}{ Formulations } \\
\hline & Sample pattern $(\mathrm{P})(\%)$ & Experimental pattern A (\%) & Experimental pattern B (\%) \\
\hline Flour without yeast & 100 & 100 & 100 \\
\hline Yacon flour & 0 & 6 & 11 \\
\hline Salt & 2 & 2 & 2 \\
\hline Granulated sugar & 1 & 1 & 1 \\
\hline Biological yeast & 4 & 4 & 4 \\
\hline Whole Milk UHT & 60 & 62 & 63 \\
\hline Vegetal hydrogenated fat & 6 & 3 & 0 \\
\hline
\end{tabular}


reference food with the area calculation determined by the Autocad technical drawing software (2008), Equation 1.

$\mathrm{GI}=\frac{\text { the glucose curve area of the test food }}{\text { the glucose curve area of the reference food }} \times 100$

The glycemic rate (GR) was calculated by multiplying the food GI by the quantity of carbohydrate present in the portion which was eaten.

\subsection{The prebiotic potential determination 'in vitro'}

The prebiotic potential followed the methodology proposed by Cambrodón and Martín-Carrón (2001), having some changes suggested by Salgado et al. (2006) and Silveira et al. (2008), in two stages: the fermentation and the study of the metabolic liquid by counting the prebiotic bacteria (Lactobacillus and bifidobacteria).
Samples containing $100 \mathrm{mg}$ each were put in $8 \mathrm{~mL}$ lab tubes within the fermentation, stored at $37^{\circ} \mathrm{C}$ in Gaspak jugs with an anaerobic system for 12 hours. Later, $2 \mathrm{~mL}$ of innocuous was added to each tube, previously prepared with latent faeces within the fermentation. This process was elaborated according to Barry et al. (1995) in the proposition of $10 \mathrm{~mL} \cdot \mathrm{g}^{-1}$ of faeces stored at $37^{\circ} \mathrm{C}$, under anaerobioses for 12 hours.

The tubes were kept in the anaerobic system, in water bath with agitation and temperature controlled at $37^{\circ} \mathrm{C}$, being under this condition/process during the fermentation period. Every 2 hours, one $1 \mathrm{~mL}$ aliquots of the metabolic liquid was used to count the homofermentative and heterofermentative bacteria.

HHD agar deferential was used to quantify and identify the homofermentative and heterofermentative bacteria,. While counting the homofermentative and heterofermentative bacteria, the metabolic liquid samples were stored on plaque surface, the incubation condition used was under $37^{\circ} \mathrm{C}$, with

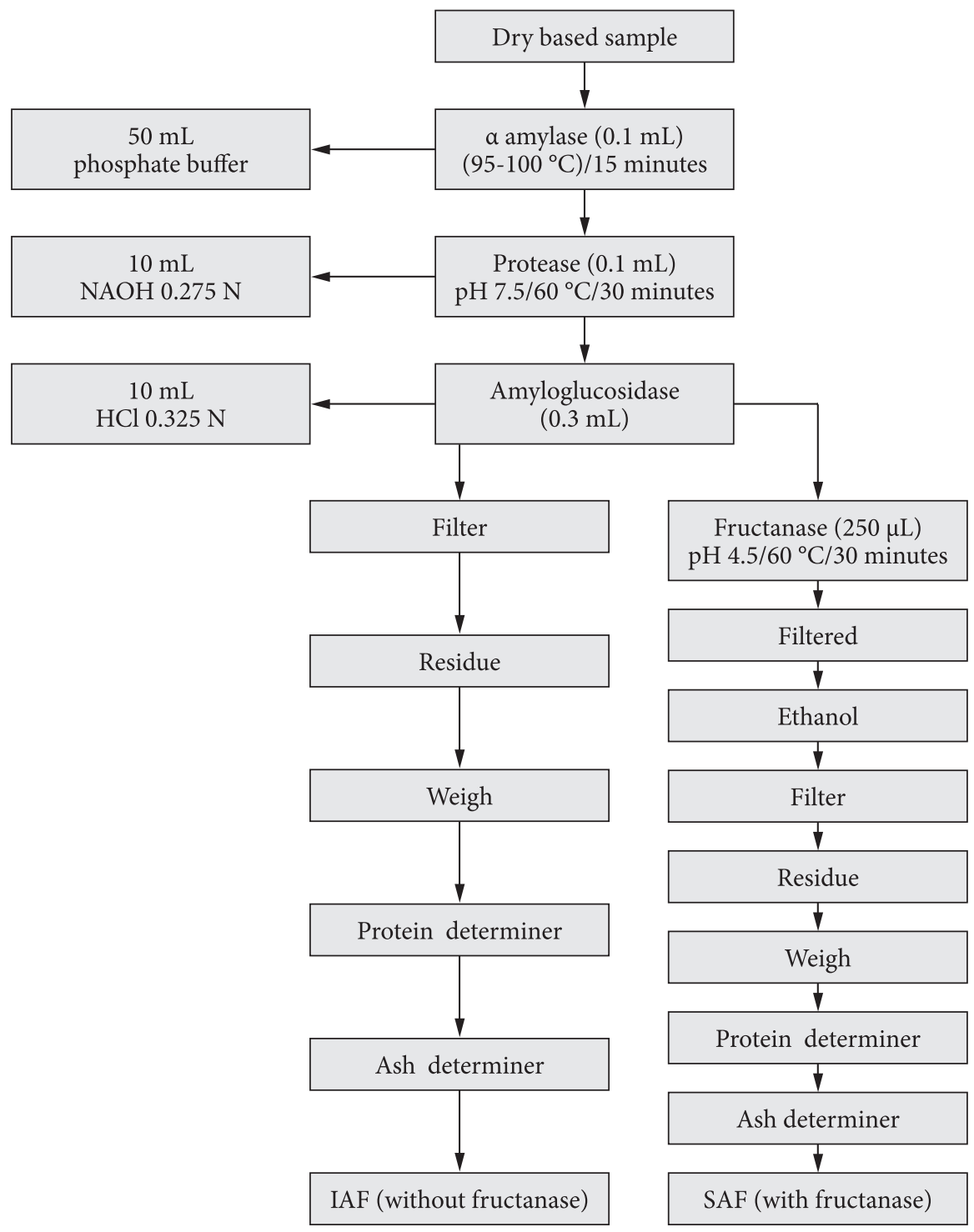

Figure 2. Analytical diagram for fiber determination (AOAC 985.29). SAF (Soluble Alimentary Fiber), IAF - (Insoluble Alimentary Fiber). 
variations of $1^{\circ} \mathrm{C}$ for 72 hours in the anaerobic system, with the production system of anaerobioses.

\subsection{The statistical analysis}

The results were found by variation analysis (ANOVA), followed by a comparison test of Ducan averages, at 5\% of significant, using the statistic programme Statistics Software (version 6.0) (2002).

\section{Results and discussions}

\subsection{The microbiological and granulometrical analysis of yacon flour}

The results of the microbiological exams for coliforms at $45^{\circ}{\mathrm{C} . \mathrm{g}^{-1}}(\mathrm{~mL})\left(10 \mathrm{UFC}^{-g^{-1}}\right)$, Bacillus cereus $\left(10^{2} \mathrm{UFC}^{-1}{ }^{-1}\right)$ and salmonella sp. (absence) were shown according to the legislation (BRASIL, 2001), thus, being in the ideal conditions for human consumption.

The raw material granulometrical characteristic is a relevant aspect for the making of industrial pasta and bread products, as the correct distribution of particles will enable a better uniformity of the product in focus. The granulometric directly influences the water absorption capacity, the sensorial characteristics (such as appearance, taste and texture) and the pasta cooking time. (BORGES et al., 2003). The results of the granulometrical analysis are depicted in Table 2.

The particle size was shown in many different ways; however, it was observed that $37 \%$ of the yacon flour particles showed an average diameter of $0,180 \mathrm{~mm}$. We should, albeit, point out that the 35 mesh granulometry presented the best quality flour for bread production, providing better results when mixed with the other ingredients. By decreasing the opening, we could observe that the yacon flour absorbed more humidity and formed unwanted lumps for the bread production. The literature is scarce in relation to yacon flour granulometry data.

According to studies with other types of flour, we have seen, in corn flour, an average diameter of $0.40 \mathrm{~mm}$ and from 0.10 to $0.15 \mathrm{~mm}$ for the rye flour. Those results were lower than the ones found in this work.

\subsection{The yacon flour and bread characterization}

Analyzing Table 3, one can see that the constitution values found were similar to those in the literature, highlighting the great tenor of carbohydrates that represents about $67 \%$ (MOSCATTO; PRUDÊNCIO-FERREIRA; HAULY, 2004).

Table 2. Size of the yacon flour particles.

\begin{tabular}{ccc}
\hline Tyler/Mesh & The kneading process $(\mathrm{mm})$ & Yacon flour $(\%$ retained $)$ \\
\hline 28 & 0,600 & 12 \\
35 & 0,425 & 17 \\
48 & 0,300 & 14 \\
60 & 0,250 & 8 \\
80 & 0,180 & 12 \\
$>80$ & $>0,180$ & 37 \\
\hline
\end{tabular}

It is important to highlight that those carbohydrates can be classified as fructans, especially frutoligossacharideo. Nevertheless, some researchers have shown that the process stages to obtain the yacon flour will considerably reduce the quantity of those nutrients at the drying stage (MUSSATTO; MANCILHA, 2007).

Comparing the yacon flour to the other ones, we observed that the humidity values were similar to the oat, corn and rice flours, while the proteins and fat were lower. As for the mineral content, we stated that it was higher $\left(4,20 \mathrm{~g} .100 \mathrm{~g}^{-1}\right)$ compared to the whole meal flour $\left(1.7 .100 \mathrm{~g}^{-1}\right)$, which is theoretically considered rich in minerals due to its lower extraction level (UNIVERSIDADE..., 2006).

The quantity of fiber was higher in the rye flour (2.3\%), and similar to the whole meal flour (15.5\%) showing the applicability of this ingredient to the bread industry having a higher tenor of fiber (UNIVERSIDADE..., 2006).

The chemical composition for the described in Table 4 depicts that the bread has significant differences toward the analyzed parameters. Silva (2007) produced a type of bread adding $25 \%$ of yacon and found different results of the chemical composition to the ones shown in this work: humidity $(3.84 \%)$, ashes $(3.49 \%)$, fiber $(3.60 \%)$, carbohydrates $(65 \%)$, fat $(0.52 \%)$ and proteins $(7.97 \%)$.

According to the results, the formulation $\mathrm{B}$ presented a higher tenor of humidity, followed by the $\mathrm{A}$ and $\mathrm{P}$ formulations, probably because of its high quantity of yacon flour (11\%), as the fructans have 'hydroxyls' groups $(\mathrm{OH})$ that are able to integrate with water, through the hydrogen bridges, which makes evaporation during the bread baking process more difficult (SILVA, 2007).

The protein content differed statistically between loaves of bread, possibly due to the differences in the milk content used in the formulation. The mineral tenor was significantly different in Bread B, a factor also attributed to a larger quantity of yacon flour being added, which had a high mineral value.

In terms of fat content, it was possible to observe a significant reduction of $44 \%$ and $84 \%$ for Bread A and B, respectively, in relation to the standard Bread, thus originating the definition "light" in fat, considering that the legislation advocates a reduction of at least 25\% (BRASIL,1998b).

Table 3. Centesimal composition of the yacon flour

\begin{tabular}{cc}
\hline Physicochemical analysis (Moist Base g. $100 \mathrm{~g}^{-1}$ ) & Yacon flour \\
\hline Humidity & 13,24 \\
Fixed Mineral Residue & 4,20 \\
Protein & 3,36 \\
Ethereal Extract & 0,19 \\
Available Carbohydrate & 66,8 \\
Soluble Fiber & 2,76 \\
Insoluble Fiber & 9,45 \\
Total Alimentary Fiber ${ }^{*}$ & 12,21 \\
V.C.T (Kcal) & 282,35 \\
\hline${ }^{*}$ Obtained by difference ${ }^{* *}$ Obtained by the adding of the soluble and insoluble fractions.
\end{tabular}


Concerning the fibre tenor, bread made with yacon flour differed statistically and is shown as a product of high tenor. According to the current Brazilian legislation, food is considered to be rich in fibre when it presents a minimum of $3 \%$, and with a high tenor, when it presents at least 6\% (BRASIL,1998a). In this way, the standard Bread can also be considered a source of such nutrient, a fact that can be explained by the possible starch resistant formation during bread storage (PEREIRA, 2007).

The carbohydrate values in formulations A and B were inferior to the ones in types of bread on the market, such as traditional sandwich loaf and "light" sandwich loaf, $49 \%$ and $46 \%$ of available carbohydrates (UNIVERSIDADE..., 2006), respectively. It is possible to show that the experimental loaves of bread presented reduced caloric value compared to the others on the market, for example: oat bread ( $\left.343 \mathrm{Kcal} .100 \mathrm{~g} \mathrm{~g}^{-1}\right)$,

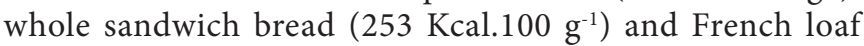
$\left(300 \mathrm{Kcal}^{1} 100 \mathrm{~g}^{-1}\right)$ (UNIVERSIDADE..., 2006).

\subsection{Glycemic Index Determination - Kinetic of the Hydrolysis of Carbohydrates}

The kinetic of the enzymatic hydrolysis of the carbohydrates (Figure 3) showed that, in the first 30 minutes, the bread with 6\% of yacon and the standard one had similar hydrolysis, but soon after that, the glucose value of the experimental bread became stable with low basal levels around 60 to $80 \mathrm{mg}^{-\mathrm{dL}^{-1}}$, inferior to the one considered of glycemic peak, which varied from 120 to $140 \mathrm{mg} \cdot \mathrm{mL}^{-1}$, possibly because of the presence of fructans, which turned into gel, thus making the access to the amylolitic enzyme difficult (SAAD, 2006).

In Table 5, the results showed that the bread containing yacon flour presented a glycemic index similar to the literature data for other types, for instance, bread with oat grains (GI $=49)$, bread with rye grains $(\mathrm{GI}=48)$, bread with cereal grains $(\mathrm{GI}=50)$ and bread enriched with fibres (FOSTER-POWELL, 2002)

According to recommendation of the American Diabetic Association (ADA, 2002) the glycemic index in bread B was considered low $(\mathrm{GI}<55)$, whereas bread $\mathrm{A}$ and the standard bread presented a moderate index (GI from 56 to 69). Concerning the GC, one can perceive that the loaves of bread presented a low glycemic charge, since GC $\leq 10$ is considered low and GC $\geq 20$ high.
The advantage of the low GI is reflected in a larger feeling of satiety (BRAND-MILLER, 2002), lingering the feedback of the cholescystokinin and glucagon hormones, which are responsible for the gastric fullness (LEMOS et al., 2002).

The glycemic charge, which expresses the quantity and quality of carbohydrates consumed, is even more satisfactory than the bread GI. The glycemic index and glycemic charge were confronted and showed a good statistical correlation $(\mathrm{r}=0.9939)$.

The results of this study tend to confirm the literature reports, which inform that there is some type of inter-relation between the glycemic index and the glycemic charge (LAU et al., 2005).

However, it is important to point out that the GI, as well as the GC cannot be considered separately in the evaluation or choice of food, since some characteristics may interfere with this parameter, among them; the type of sugar (glucose, fructose, sucrose, lactose); the tenor of amylase and amylopectin; the presence of resistant starch; the thermal processing, the size of the particles; and other food constituents, such as fat and starchprotein and starch-lipids interactions, quantity and quality of carbohydrates (ADA, 2002; MONRO; SHAW, 2008).

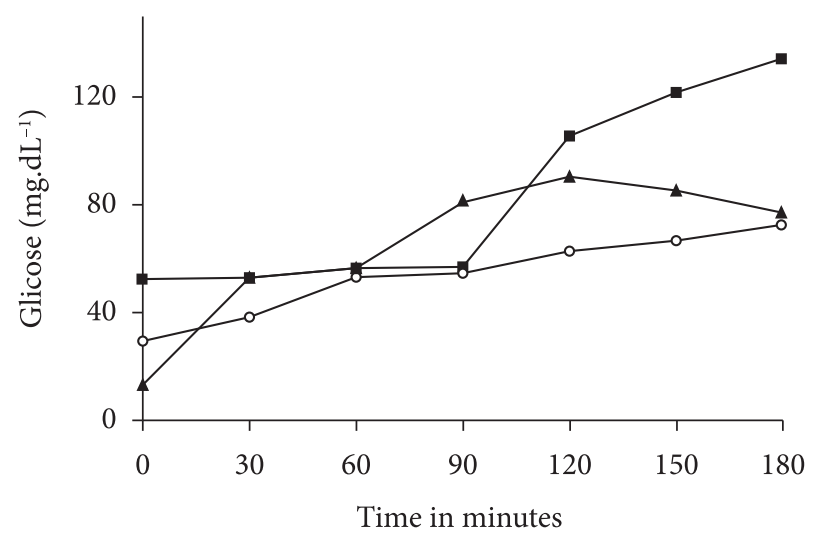

Standard bread ( without yacon flour) Bread with $6 \%$ yacon flour Bread with $11 \%$ yacon flour

Figure 3. Enzymatic hydrolysis - Kinetic of the carbohydrate in bread.

Table 4. Chemical Composition of Bread Formulations.

\begin{tabular}{|c|c|c|c|}
\hline Analysis Moist Base & $\begin{array}{c}\text { Standard Bread } \\
\text { (without yacon flour; } 6 \% \text { fat) }\end{array}$ & $\begin{array}{c}\text { Sample A } \\
\text { (6\% yacon flour; } 3 \% \text { fat) }\end{array}$ & $\begin{array}{c}\text { Sample B } \\
(11 \% \text { yacon flour; } 0 \% \text { fat })\end{array}$ \\
\hline Moist & $38,80^{c}$ & $39,13^{\mathrm{b}}$ & $41,24^{\mathrm{a}}$ \\
\hline Fixed Mineral Residue & $2,83^{\mathrm{b}}$ & $2,80^{\mathrm{b}}$ & $2,93^{\mathrm{a}}$ \\
\hline Protein & $11,82^{\mathrm{b}}$ & $11,56^{\mathrm{c}}$ & $12,37^{\mathrm{a}}$ \\
\hline Ethereal Extract & $8,00^{\mathrm{a}}$ & $4,47^{\mathrm{b}}$ & $1,26^{\mathrm{c}}$ \\
\hline Available Carbohydrate* & $32,82^{\mathrm{b}}$ & $33,96^{\mathrm{a}}$ & $31,81^{\mathrm{c}}$ \\
\hline Soluble Fiber & $1,84^{\mathrm{c}}$ & $3,17^{\mathrm{b}}$ & $3,41^{\mathrm{a}}$ \\
\hline Insoluble Fiber & $3,89^{\mathrm{c}}$ & $4,91^{\mathrm{b}}$ & $6,98^{\mathrm{a}}$ \\
\hline Total Alimentary Fiber** & $5,73^{\mathrm{c}}$ & $8,08^{\mathrm{b}}$ & $10,39^{\mathrm{a}}$ \\
\hline V.C.T (Kcal) & $250,56^{\mathrm{a}}$ & $222,31^{\mathrm{b}}$ & $188,06^{\mathrm{c}}$ \\
\hline
\end{tabular}

Same letters in the horizontal position do not differ significantly to the level of $5 \%$ of significance. ${ }^{\star}$ Obtained by difference ${ }^{* *}$ Obtained by the adding of the soluble and insoluble fractions. 
The type of carbohydrate influences the glycemic response, as Brasil (2006) used 6\% of inulin in bread and found a high GI (82), it is possible that the isolated inulin has not had a positive effect in this parameter. On the other hand, bread with 6 and $11 \%$ of yacon flour presented reduced indices, probably because of the factors previously mentioned (Table 5).

\subsection{Prebiotic potential “in vitro"}

The analysis of the plates showed the presence of smooth colonies with complete, regular, shiny and blue brims, which indicate the presence of homofermentative bacteria and as their representative, some species of lactobacilli stand out. These, together with the Bifidobacterium, are considered prebiotic micro-organisms (ANTUNES et al., 2007).

The bacteria of the Bifidobacterium type, recognized as heterofermentatives, were found after 12 hours of fermentation in smaller quantities than the homofermentatives (Table 6). The reduced counting of this micro-organism can take place from a possible competition between the lactobacillus and Bifidobacterium, observing that the bifidobacteria are more demanding and less active than the lactobacilli and require more special conditions regarding their growth (BARRETO et al., 2003).

A similar behaviour was observed by Thamer and Penna (2005) when evaluating the lack of growth of Bifidobacteria in FOS-added milk products.

Bread B presented a larger count of prebiotic bacteria due to the fermentative substratum tenor (11\% of yacon flour) added. Cunha et al., (2008), reported that other variable factors can influence the prebiotic counting, for example: the quantity of inoculated micro-organisms, the used culture, the interaction among other present species, and the presence of dissolved oxygen.
The type of fermentative carbohydrate can also influence the lactobacilli growth because they have more affinity with starch and fructans, and the bifidobacteria with pectin and Arabic gum, which explains the large growth of lactobacilli during the fermentative process of the loaves of bread (Table 6) (CAMBRODÓN; MARTÍN-CARRÓN, 2001).

Studies "in vitro" have also demonstrated that the use of approximately $5 \mathrm{~g}$ /day of FOS alone or added to juices and yoghurts could raise the probiotic bacteria counting (FREITAS; JACKIX, 2005).

The bacteria counting (Table 6) of the formulations during fermentation varied from $10^{7}$ to $10^{10}$ colony former unit $(\mathrm{CFU}) / \mathrm{mL}$, which will certainly cause the colonization of the referred cultures in the intestines, in order to carry out the probiotic effects at a minimum of $10^{6}$ CFU.mL ${ }^{-1}$ (BRASIL, 2005).

Comparing the results obtained in Table 6, one can observe that bread with yacon flour has prebiotic potential, as it caused the development of probiotic bacteria much more expressively than the inoculums.

The standard bread also presented a larger growth than in the inoculum, especially after 4 hours of fermentation, a fact that can be explained by the constituents in its composition, such as wheat, which has fructan and resistant starch type traits, both good substracta for the anaerobic, being considered prebiotic agents (SALGADO et al., 2006).

\section{Conclusions}

The addition of yacon flour made bread with high tenor of fibers, "light" in fat and having low glycemic charge. Bread containing $11 \%$ and $6 \%$ of yacon flour were classified as low and moderate glycemic indices, respectively. Regardless of the yacon flour tenor, the loaves of bread presented prebiotic potential for causing the probiotic bacteria growth during the "in vitro" fermentation.

Table 5. Glycemic index 'in vitro’ and glycemic amount in bread.

\begin{tabular}{lcc}
\hline Sample & Glycemic index (\%) & Glycemic amoung (100 g portion) \\
\hline Standard bread (bread without yacon flour, with 6\% fat) & 63 & 10,30 \\
Sample A (bread with 6\% of yacon flour, 3\% fat) & 59 & 10,02 \\
Sample B (bread with 11\% of yacon flour, no fat) & 42 & 6,68 \\
\hline
\end{tabular}

Table 6. Counting of probiotic bacteria in bread formulations.

\begin{tabular}{|c|c|c|c|c|c|c|c|c|}
\hline \multirow[t]{2}{*}{ Bread Yeast } & \multicolumn{2}{|c|}{$\begin{array}{l}\text { Lactent Faeces } \\
\text { (harmeless) }\end{array}$} & \multicolumn{2}{|c|}{$\begin{array}{c}\text { Standard Bread } \\
\text { (without yacon flour; } 6 \% \text { of fat) } \\
\text { CFU.g } \\
\end{array}$} & \multicolumn{2}{|c|}{$\begin{array}{c}\text { Sample A } \\
\text { (6\% of yacon flour; } 3 \% \text { of fat) } \\
\text { CFU.g }{ }^{-1}\end{array}$} & \multicolumn{2}{|c|}{$\begin{array}{c}\text { Sample B } \\
\text { (11\% of yacon flour; 0\% of fat) } \\
\text { CFU.g- }\end{array}$} \\
\hline & Lacto & Bif. & Lacto. & Bif. & Lacto. & Bif. & Lacto. & Bifido. \\
\hline 0 hour & $3,0 \times 10^{7}$ & $2,0 \times 10^{7}$ & $1,1 \times 10^{7}$ & NI & $5,6 \times 10^{7}$ & NI & $3,4 \times 10^{8}$ & NI \\
\hline 2 hours & $4,2 \times 10^{7}$ & NI & $1,8 \times 10^{7}$ & NI & $7,1 \times 10^{7}$ & NI & $3,3 \times 10^{8}$ & NI \\
\hline 4 hours & $1,2 \times 10^{7}$ & NI & $2,0 \times 10^{7}$ & NI & $7,3 \times 10^{7}$ & NI & $1,4 \times 10^{8}$ & NI \\
\hline 6 hours & $1,5 \times 10^{7}$ & NI & $2,0 \times 10^{7}$ & NI & $9,8 \times 10^{7}$ & NI & $4,7 \times 10^{7}$ & NI \\
\hline 8 hours & $1,0 \times 10^{7}$ & NI & $4,9 \times 10^{7}$ & NI & $7,3 \times 10^{7}$ & NI & $1,5 \times 10^{8}$ & NI \\
\hline 10 hours & $2,1 \times 10^{7}$ & NI & $4,8 \times 10^{7}$ & NI & $6,1 \times 10^{7}$ & NI & $2,5 \times 10^{8}$ & NI \\
\hline 12 hours & $1,2 \times 10^{7}$ & NI & $4,0 \times 10^{7}$ & $\mathrm{NI}$ & $6,4 \times 10^{7}$ & NI & $1,4 \times 10^{10}$ & $5,0 \times 10^{8}$ \\
\hline
\end{tabular}

Lacto. $=$ Lactobacillus, Bif. $=$ Bifid bacteria, $\mathrm{CFU}=$ Colony Forming Units, NI $=$ Not identified Ferm. $=$ Time of fermentation. 


\section{References}

AMERICAN DIABETES ASSOCIATION - ADA. 2002. Evidencebased nutrition principles and recommendations for the treatment and prevention of diabetes and related complications. Diabetes Care, 25, (1), 202-12.

ANTUNES, A. E. C. et al. Probióticos: agentes promotores de saúde. (Probiotics: health promoters). Nutrire, v. 32, p. 113-132, 2007.

ARENDT, E. K. et al. Evaluation of the effects of fat replacers on the quality of wheat bread. Journal of Food Engineering, v. 56, p. 265-267, 2003. http://dx.doi.org/10.1016/S0260-8774(02)00266-2

ASSOCIATION OF OFFICIAL ANALYTICAL CHEMISTRY - AOAC. Official Methods of Analysis of the Association of Official Analytical Chemistry. 13th ed. Washington: AOAC, 2002.

BARRETO, G. P. M. et al. Quantificação de Lactobacillus acidophilus, bifidobactérias e bactérias totais em produtos probióticos comercializados no Brasil. (Estimation of Lactobacillus acidophilus, bifidobacteria and total bacteria in probiotic products traded in Brazil). Brazilian Journal of Food Technology, n. 120, p.119-126, 2003.

BARRY, J. L et al. Estimation of fermentability of dietary fiber in vitro: a European Interlaboratory study. British Journal of Nutrition, v. 74, p. 303-322, 1995. http://dx.doi.org/10.1079/BJN19950137

BORGES, J. T. S. et al. Propriedades de cozimento e caracterização físico-química de macarrão pré-cozido à base de farinha integral de quinoa (Chenopodium quinoa, Wild) e de farinha de arroz (Oryza sativa, L) polido por extrusão termoplástica. Boletim CEPPA, v. 21, n. 2, p. 303-322, 2003.

BRAND-MILLER, J.; GILBERTSON, H. Practical aspects of meal planning using the glycemic index. In: WORKSHOP GLYCEMIC INDEX AND HEALTH: the Quality of the Evidence, 2002, Bandol, France. Proceedings... Bandol: FAO/Danone Vitapole, 2002.

BRASIL. Ministério da Sáude. Agência Nacional de Vigilância Sanitária. Portaria n. 27, de 13 de janeiro de 1998a. Regulamento Técnico referente à Informação Nutricional Complementar. Diário Oficial da República Federativa do Brasil, Brasília, DF, 15 jan 1998. Disponível em: <www.anvisa.gov.br>. Acesso em: 12 ago. 2008.

BRASIL. Ministério da Sáude. Secretaria de Vigilância Sanitária. Portaria SVS n. 29 de 13 de janeiro de 1998b. Regulamento técnico para fixação de identidade e qualidade de alimentos para fins especiais. Diário Oficial da República Federativa do Brasil, Brasília, DF, 30 mar. 1998b. Disponível em: <www.anvisa.gov.br>. Acesso em: 12 mar. 2008.

BRASIL. Ministério da Sáude. Agência Nacional de Vigilância Sanitária. Resolução RDC n. 12, de 2 de janeiro de 2001. Regulamento técnico sobre padrões microbiológicos para alimentos. Diário Oficial da República Federativa do Brasil, Brasília, DF, 10 jan. 2001. Disponível em: <http://www.anvisa.gov.br>. Acesso em: 2 jan. 2008.

BRASIL, J. A. Efeito da adição de inulina sobre os parâmetros de pão sensorial, físico e nutricional. 2006. 65 f. Dissertação (Mestrado em Nutrição)-Universidade Federal de Pernambuco, Recife, 2006.

CAMBRODON, I. G., MARTIN-CARRON, N. Fermentación colónica de fibra dietética y almidón resistente. In: LAJOLO, F. M. et al. Fibra dietética em Iberoamérica: tecnologia y salud. São Paulo: Varela, 2001.

CUMMINGS, J. H.; STEPHEN, A. M. Carbohydrate terminology and classification. European Journal of Clinical Nutrition, v. 61, n. 1, p. 5-18, 2007. PMid:17992187. http://dx.doi.org/10.1038/ sj.ejcn. 1602936
CUNHA, T. M. et al. A Physic-chemical, microbiologic and reologic evaluation of dairy drinks and fermented milk with addition of probiotics. Semina: Ciências Agrárias, v. 29 n. 1, p. 103-116, 2008.

DUARTE, M. R.; WOLF, S.; PAULA, B. G. Smallanthus sonchifolius (Poepp.) H. Rob. (yacón): microscopic identification of leave and trunk pharmacognostic quality control. Brazilian Magazine of Pharmaceutic Sciences, v. 44, n. 1, p. 157-164, 2008.

FOSTER-POWELL, K.; HOLT, S. H. A.; BRAND-MILLER, J. C. International table of glycemic index and glycemic load values: American Journal Clinical Nutrition, v. 76, n. 5, 56p, 2002.

FREITAS, D. G. C.; JACKIX, M. N. H. Effects of drink added with frutoligosacarideo and pectin at the level of cholesterol and bifideobacteria stimulation in hyper colesterolemic hamsters. Brazilian Journal Food Technololy, v. 8, n. 1, p. 81-86, 2005.

GÕNI, I.; GARCIA-ALONSO, A.; SAURO-CALIXTO, F. A. A starch hydrolysis procedure to estimate glycemic index. Nutrition Research, v. 17, n. 3, p. 427-437, 1997. http://dx.doi.org/10.1016/ S0271-5317(97)00010-9

LAU, C. et al. Dietary glycemic index, glycemic load, fiber, simple sugars, and insulin resistance: the Inter99 study. Diabetes Care, v. 28, p. 1397-403, 2005. PMid:15920058. http://dx.doi.org/10.2337/ diacare.28.6.1397

LEMOS, M. C. C. et al. Glycemic index of tropical fruits in normal individuals, patients with type 2 diabetes and patients with impaired glucose tolerance. Anais Faculdade Médica, v. 74, n. 1, p. 50-53, 2002.

MATSUO, R. R.; DEXTER, J. E. Comparison of experimentally milled durum wheat of semolina produced by same Canadian commercial mills. Cereal Chemistry, v. 57, p. 117-122, 1980.

MONRO, J. A.; SHAW, M. Glycemic impact, glycemic glucose equivalents, glycemic index, and glycemic load: definitions, distinctions, and implications. American Journal of Clinical Nutrition, v. 87, p. 237-243, 2008.

MOSCATTO, J. A.; PRUDENCIO-FERREIRA, S. H.; HAULY, M. C. O. Yacon floour and inulin as ingredients in the formulation of chocolate cake. Food Science and Technology, v. 24, n. 4, p. 634-640, 2004.

MUSSATTO, S. I.; MANCILHA, I. M. Non-digestible oligosaccharides: A review. Carbohydrate Polymers, v. 68, n. 3, p. 587-597, 2007. http://dx.doi.org/10.1016/j.carbpol.2006.12.011

PEREIRA, K. D. Resistant starch, the last generation in the control of energy and healthy digestion. Food Science and Technology, Campinas, v. 27, n. 1, p. 89-93, 2007.

SAAD, S. M. I. Probiotics and Prebiotics: the estate of art. Brazilian Journal of Pharmaceutical Science, v. 42, n. 1, p. 1-16, 2006.

SALGADO, S. M. et al. Physiological response of makassar beans starch In vitro) (Vigna unguiculata L. Walp). Brazilian Journal of Food Technology, v. 9, n. 4, p. 297-303, 2006.

SILVA, A. S. S. Raiz da Yacon (Smallanthus sonchifolius Poepping \& Endlicher) como fonte de fibras alimentares, sua caracterização físico-química, seu uso na panificação e sua influência no pósglicemia prandrial. 2007. $160 \mathrm{f}$. Tese (Doutorado em Tecnologia dos Alimentos)-Universidade Federal de Santa Catarina, Florianópolis, 2007.

SILVEIRA, K. C. et al. Beverage based on pumpkin flocs with inulin: prebiotic characteristics and acceptability. Revista de Nutrição, v. 21, n. 3 , p. $267-276,2008$. http://dx.doi.org/10.1590/S141552732008000300001

STATISTICA. Versão 6.0 for windows volume IV. 2002. Tulsa-OK, USA:Statsoft Inc (software). 
THAMER, L. G.; PENNA, A. L. B. Caracterização de bebidas lácteas funcionais fermentadas por probióticos e acrescidas de prebiótico. Ciência e Tecnologia de Alimentos, v. 26, n. 3, p. 589-95, 2006. http://dx.doi.org/10.1590/S0101-20612006000300017

UNIVERSIDADE DE CAMPINAS - UNICAMP. Tabela brasileira de composição de alimentos - TACO. Versão 2. 2. ed. Campinas: UNICAMP/NEPA, 2006. 113 p.

VALENTOVÁ, K. et al. Maca (Lepidium meyenii) and yacon (Smallanthus sonchifolius) in combination with silymarin as food supplements: In vivo safety assessment. Food and Chemical Toxicology, v. 46, p. 1006-1013, 2008. PMid:18054420. http://dx.doi.org/10.1016/j.fct.2007.10.031

VALENTOVÁ, K.; ERSEN, F.; ULRICHOVA, J. Radical scavenging and anti-lipoperoxidative activities of Smallanthus sonchifolius leaf extracts. Journal of Agricultural and Food Chemistry, v. 53, p. 5577-5582, 2005. PMid:15998117. http://dx.doi.org/10.1021/ jf050403o 